\title{
A comparison between steroidal hormones in follicular fluids and histological change of the dominant and cystic follicles of local breeding cows.
}

\author{
A. K. Al-Gewary Dh. H. Al-Delemy Z. M. Ali \\ Coll. of Vet. Med./ Unive. of Al-Qadissiya
}

\begin{abstract}
The cystic ovarian follicle are a serious cause of reproductive failure in cattle because they occur frequently and prolong the intervals from postpartum to first estrus and conception. The paired ovaries were collected from forty four slaughtered cow after examination by rectal palpation to diagnosis of the cystic follicle stricter, the local breeding cow were primarily AlGenobea , Al-Kradea and Al- Shrabea cow, the age of its cow are (4-6) years but the reproductive status were unknown. The cysts follicle fluids contain high significantly of oestradiol and progesterone $(\mathrm{p}>0.05)$ than the dominant follicle fluids. The histological characteristics of the dominant follicles $(17-25 \mathrm{~mm})$ are shown Small antral and have a granulosa cell layer and internal theca cell layer, but the cystic follicles which presented the large granulose cell layer, which was basically a poly-layer .Aim of this studies are comparison of the estradiole (E2) \& progesterone ( $\mathrm{P} 4)$ concentrations in the follicular fluids of the dominant follicles and cystic follicles, with studies of the histological change between the follicular walls.
\end{abstract}

\section{Introduction}

The cystic ovarian follicle (COF) are one or more ovarian follicular structures at least $25 \mathrm{~mm}$ or greater in diameter that persist on the ovary for at least 10 days in the absence of a corpus luteum. (1,2).The physiology and etiology of COF is poorly understood $(3,4)$, however there is much conjecture regarding of the biological cause of COF like the altered of the pre-ovulatory surge from the hypothalamus-pituitary is either absent or insufficient in occurs at the wrong time during dominant follicle maturation, which leads to cyst formation (56).The Follicular fluid (FF) of $\mathrm{COF}$ have a high estrogen(E2) concentration, (7-8-9) , and characterized by thin walls and produce very small amounts of progesterone (P4). (10) .The COF steroidogenic contained were (E2:P4>1 and $\mathrm{P} 4<100 \mathrm{ng} / \mathrm{ml}$ in $\mathrm{FF}$ )

\section{Materials and Methods}

Instruments.\& Equipments . according of (11-12) .(13) can be observation of the histological notation on the Graafian Follicles which protrudes from surface of the ovary and the granulosa layer is event out, to form together with the two layer, theca interna and theca externa of the wall of the Follicle , and presence of the granulosa cell layer in normal ovary and COF (14), but the theca interna was thinner than that in normal ovaries, as to thickened or absent granulosa cell layer In cows with cystic follicle (15). The histological of normal and COF walls and obvious multilayered in a parallel with the basement membrane separating granulosa from theca cells.(14).

used in this study with their companies and countries of origin. 
AL-Qadisiya Journal of Vet.Med.Sci. of $5^{\text {th }}$ conference 21-22 Nov. 2012

Vol. 11

No. 3

2012

Table (1) : The instruments \& Equipments which used in this study with their companies and countries of origin.

\begin{tabular}{|l|l|l|l|}
\hline No & Instruments.\& Equipments & Company & Country \\
\hline 1. & Digital Verniaer & RESHAN & CHINA \\
\hline 2. & Digital camera & SONY & CHINA \\
\hline 3. & Freezer & CONCORD & LEBANON \\
\hline 4. & Hot plate & LEITZ & GERMANY \\
\hline 5. & Magnatic stirrer Bar & NUORA & USA \\
\hline 6. & Microscope slides \& Cover glass & SAIL BRAND & MALAYSIA \\
\hline 7. & Microscope with camera & LEITZ & GERMANY \\
\hline 8. & Oven & QALLENKHAMP & GERMANY \\
\hline 9. & Rotary microtom & LEITZ1512 & GERMANY \\
\hline 10. & Water bath & MEMERT & GERMANY \\
\hline
\end{tabular}

\section{Chemicals} Table (2): The chemicals are used in this study and their sources.

\begin{tabular}{|l|l|l|l|}
\hline No. & Chemical & Company & Country \\
\hline 1. & Acidic alcoholic eosin & RIEDEL- DEHAENAG & GERMANY \\
\hline 2. & Ethanol $1000 \%$ & LABORT & INDIA \\
\hline 3. & Eosine \& Hematoxylin & PROLABO- MERCK & CE-EMB \\
\hline 4. & Formalin $10 \%$ & BDH-CHEMICAL LTD & ENGLAND \\
\hline 5. & Paraffin wax & PROLABO- MERCK & CE-EMB \\
\hline 6. & H2SO4 & BDH-Chemical Ltd & ENGLAND \\
\hline 7. & Glycerin & BDH-Chemical Ltd & ENGLAND \\
\hline 8. & Xylene & BDH-Chemical Ltd & ENGLAND \\
\hline
\end{tabular}

\section{Experimental animals ( Local cow)}

The local breeding cows are characteristic by low milk and beefs production, however not available true description to any types and rare the studies on it, the main types which finding in Iraq from class of IndiaZebu., like a: Al-Genobea cow, localized in Southeast \& center of Iraq ,b: Al-Kradea cow in Northeast of Iraq, c: Restakii cow in Middle area around of Babylon \& Bagdad.In the presence study was carried out in four governorates include Al-Diwaniya , Babylon, Karblaa and Al-Najaf Al-

The chemicals which use in our study and with their companies and countries of origin. 
AL-Qadisiya Journal of Vet.Med.Sci. of $5^{\text {th }}$ conference 21-22 Nov. 2012 Vol. $11 \quad$ No. 3

persisted follicles (25-40)mm. in diameter, without presence of any leuteal tissue on both ovaries.

\section{Collection of the ovaries.}

The Ovaries were obtained from cows slaughtered in the estrous cycle stages was defined by macroscopic observation of the ovaries (color, consistency, corpus luteum (CL) stage, number, and size of follicles) and the uterus (color, consistency, and mucus) according of description by (16).Then the Paired ovaries were collected immediately within (10-20) minute after slaughter, transported by $\mathrm{Cool}$ box $\left(4^{\circ} \mathrm{C}\right)$ to the laboratory of alnajaf vet. Hospital and rinsing briefly in ethanol
2012

(70\%), only follicles which appeared healthy which having transparent follicular wall and fluid, with signs of mucus production in the uterus and cervix. Selected the ovaries were had follicles in sized (17-25) $\mathrm{mm}$ and $\geq(25)$ $\mathrm{mm}$ in diameter assumed to be dominant and COF , according of (17).

Histological study.

Preparation of follicular wall to histological examination.

The Follicular wall were section by scissor after aspiration of the FF, and fixed with $10 \%$ formalin until performed of the histological section , as in the figure (1).

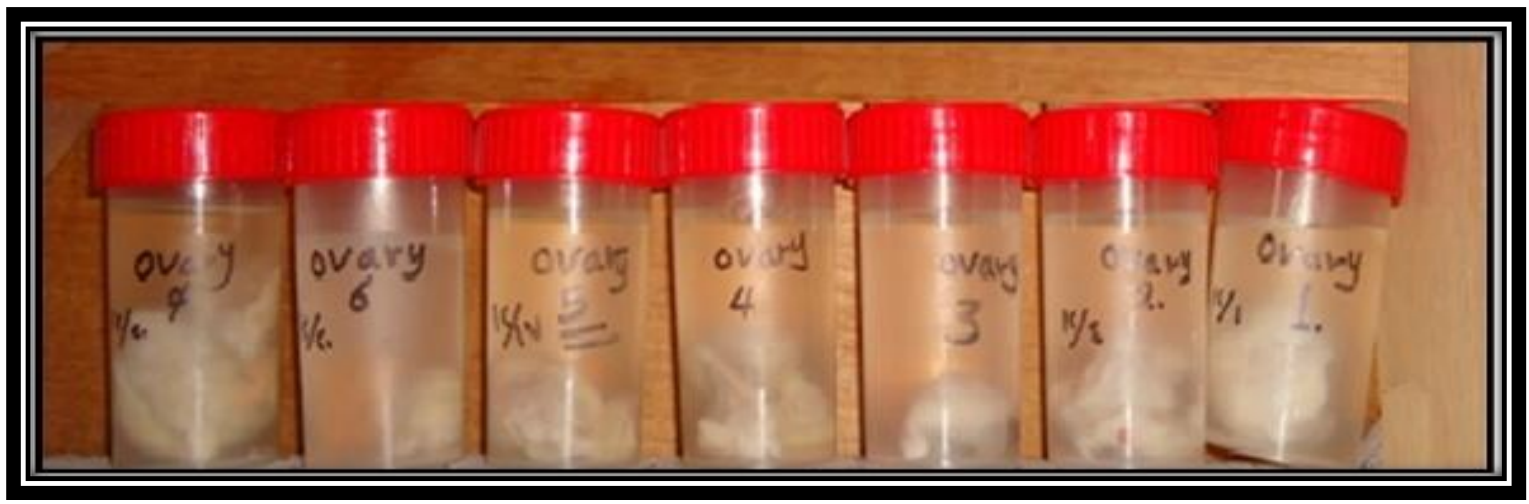

Figure (1): collection of the follicular walls in formalin $10 \%$.

\section{Histological section:}

Performed of the histological section according to methods of (21-22)

1-Fixation of follicular wall done by using Formalin (10\%).

2- Washing the samples in water for 3 hours to remove the formalin, then the samples entered to a graded series of increasing ethanol concentration which were: $70 \%$, $80 \%, 90 \%, 95 \%$ and $100 \%$ for about $1-2 \mathrm{~h}$. for each concentration.

3-Performance the clearing process by used of Xyelene for 1-1.5 hours.

4-Infiltration: by using liquid paraffin in 56$58 \mathrm{c}$ for 2 times.

5 -Embedding of the sample in fresh paraffin wax and put in oven $\left(58 c^{\circ}\right)$ in three pass, for each pass and leave it in room temperature to be hard then released from the containers and put it in freeze, then pouring in wax template 6-Section the samples by used the rotary microtome to 5 micron thickness then transfers to water bath $\left(45 \mathrm{c}^{\mathrm{o}}\right)$ and painted albumen with glycerin $(1: 1)$.

7-Stanning by use Hematoxylin and Eosin .

8- Mounting the slides with the sticky Distrene- Plasticzer-Xylen material

\section{Histological examination.}

Examination of this sample by used the microscope with camera to determined of the graneulosa cell layer thickness by optical measure in the microscope lens.

\section{Concentration of Estradiol \& Progesterone hormones in the Follicular Fluids}

According of described methods by (18), the FF was collected from $\mathrm{COF}(\mathrm{n}$ 
AL-Qadisiya Journal of Vet.Med.Sci. of $5^{\text {th }}$ conference 21-22 Nov. 2012

Vol. 11

$=21)$ which have larger size $(>25 \mathrm{~mm}$.) and non-cystic healthy follicles $(n=24)$ with size from $17-25 \mathrm{~mm}$. , the needle attached to disposable syringe $(10 \mathrm{ml})$ was inserted into a follicle and fluid
No. 3

inside was aspirated gently figure (2) , and centrifuged (2000 rpm for $10 \mathrm{~min}$.) ,then was stored at $-20{ }^{\circ} \mathrm{c}$ until hormone measurement by use Radioimmunoassay (RIA) method.

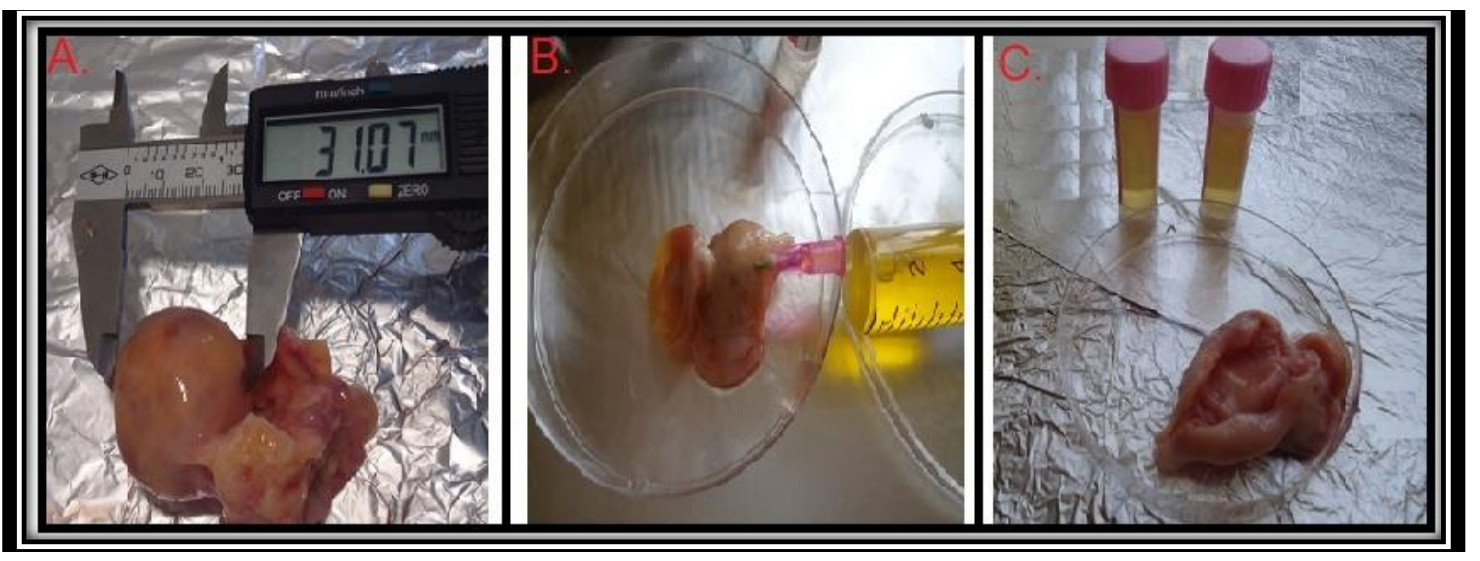

Figure (2): Follicular fluid collection, A. measurement of follicular size by Digital Verniaer ,B. aspiration of follicular fluid by use aseptic syringe with gauge (18) needles, C. spilling of follicular fluid in the venoject tubes , and stored in $(-20) \mathrm{c}^{\circ}$, until hormonal analysis.

The Radioimmunoassay method.

According to described of (19-20), we performing the RIA method by following steps .

A. Add $50 \mu \mathrm{l}$. of FF in antiprogesterone antibody-coated tubes, or (anti- estrogen antibody-coated tubes).

B. Add Traccer Labeled progesterone or(Labeled estrogen) $500 \mu 1$.

C. Incubated this mixed for three hours in water bath at $(18-25) \mathrm{c}^{\circ}$, for with shaking system in 350 shocks/minute. D. Infuse of the tube contained which not binding with antibody.

E. Account of the antibody which contacted with sample for each minuet, count per mints bound by GammaCount depending on standard curve which specific to progesterone or (estradiol hormone) in $\mathrm{ng} / \mathrm{ml}$.

\section{Results.}

\section{Collection of the ovaries.}

The collection ovaries contend only follicles which appearance a healthy follicles which having transparent follicular wall and fluids, with signs of mucus production in the uterus and cervix, in our study brought to (23) samples agree with that signs, also this samples which have related in size 19.93 (17.6$23.4) \mathrm{mm}$. figure (3.4), yet according to the clinical signs, rectal palpation and hormonal measurement, we found (21) samples have large (un-ovulation persistence) follicles on the ovary in 37.56 (31-40) mm. (table ,3) ,considered as a COF. Figure $(5,6,7,8)$ 


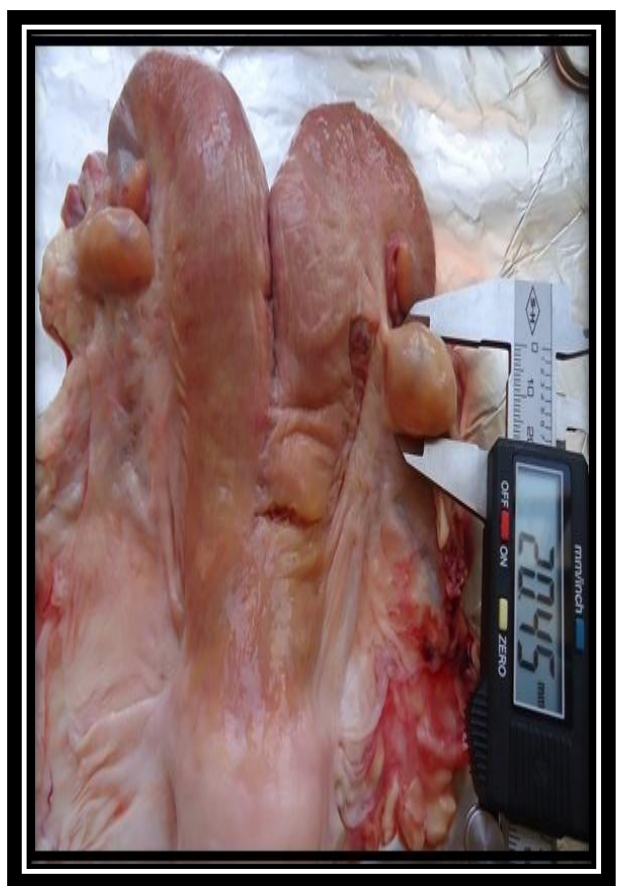

Figure (3):Female genitalia, the diameter follicle on the right ovary (20.4) $\mathrm{mm}$ with presence a remind of corpus leutum to previous estrus cycle on the left ovary

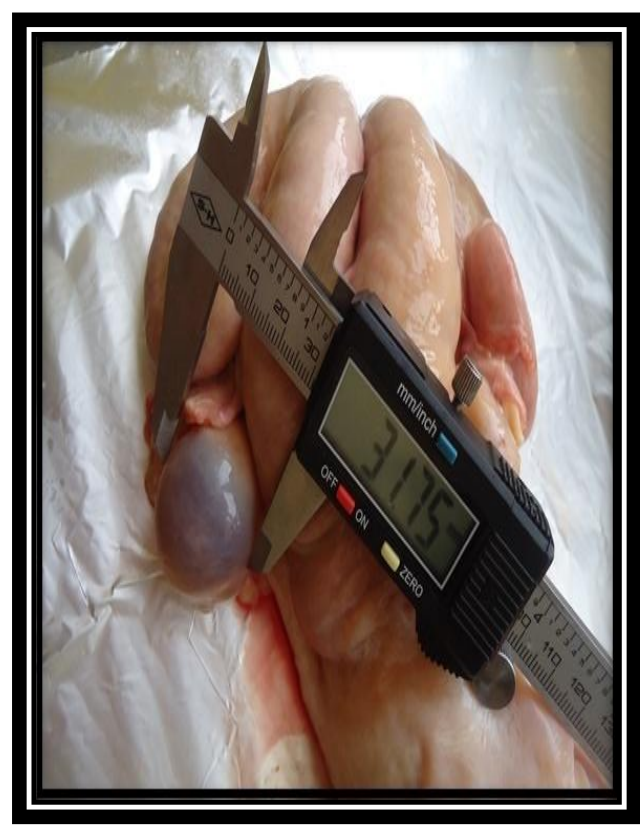

(6):Female genitalia, the diameter of follicle on right ovary (39.2) $\mathrm{mm}$ with with absence of any leuteal tissue on ovaries.

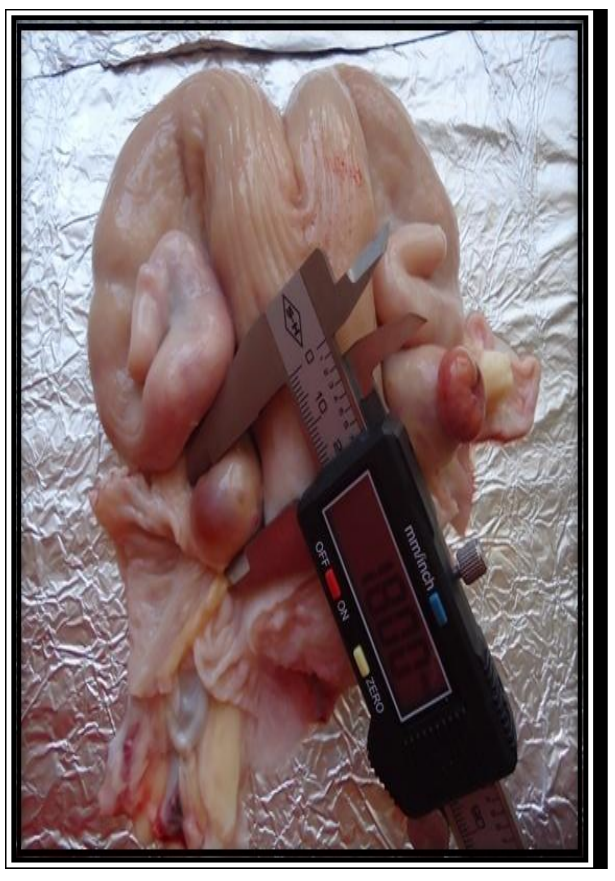

Figure (4):Female genitalia, the follicle on the left ovary (18) $\mathrm{mm}$. with persence a remind of corpus leutum to previous estrus cycle on the right ovary.

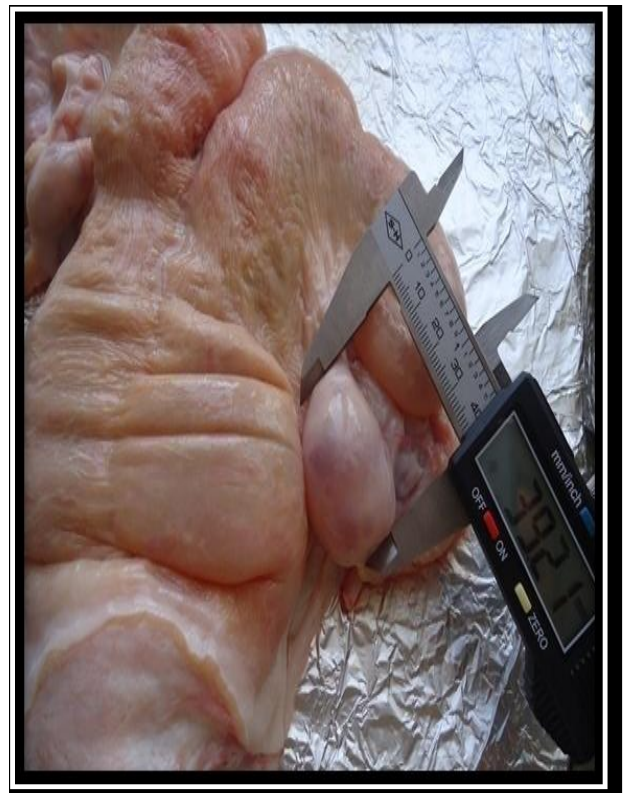

Figure (5):Female genitalia, the diameter follicle on the left ovary $(31.7) \mathrm{mm}$

Figure

of 


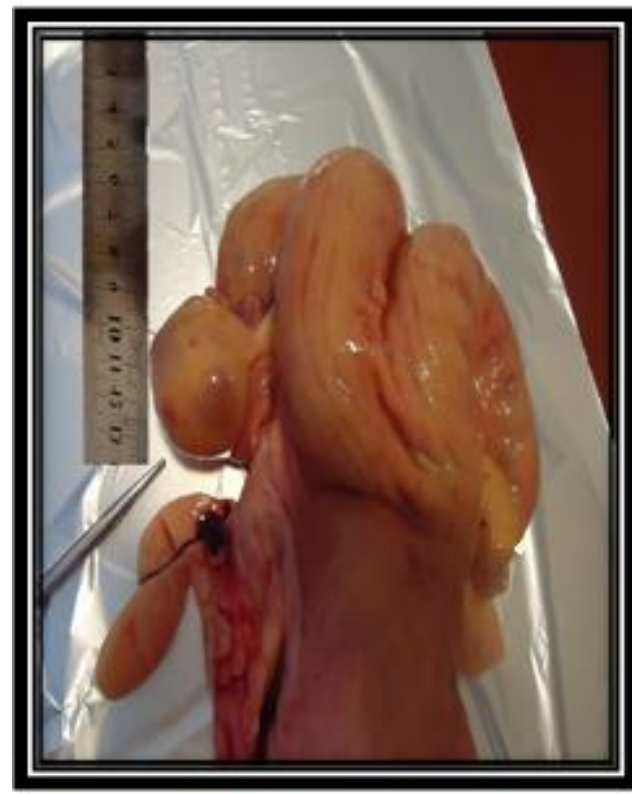

Figure (7):Female genitalia, the diameter of follicle on the left ovary $(40) \mathrm{mm}$. with absence of any leuteal tissue on both ovaries

\section{Histologica characteristics.}

The thickness of the granulosa cell layers was determined by measuring the image on the light microscope with micrometer, we detected that the thickness of the granulosa layer of COF was higher (193.18 range 175$213 \mu \mathrm{m}$.$) than did granulose cell layer$ thickness of DF which are 57.69 (26.25-75) $\mu \mathrm{m}$.when compared with the thickness for DF granulose cell layer as has been in table (3), it will be seen that the COF contain high significantly of thickness $(p>0.05)$ than granulose cell layer of $\mathrm{DF}$, and on the

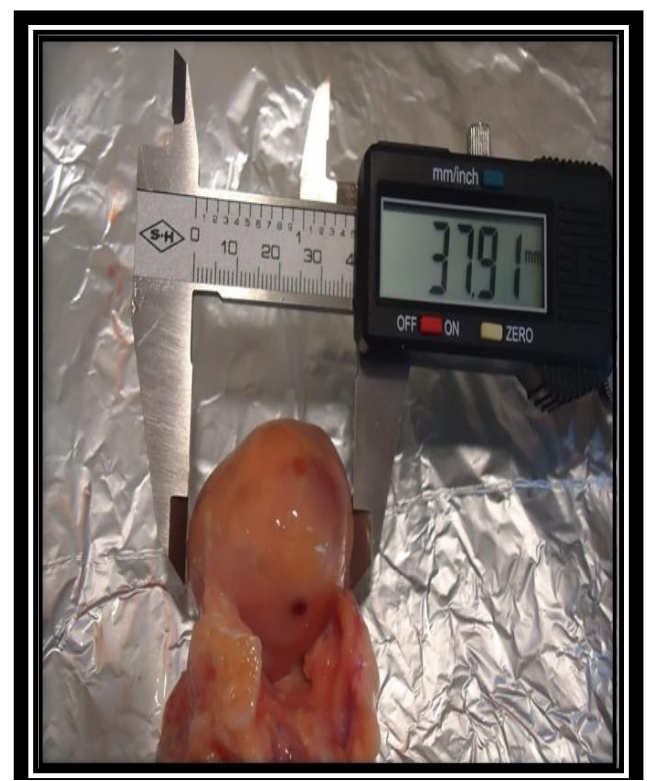

Figure (8):follicle with diameter(37.91) $\mathrm{mm}$.

other hand the follicular wall changed in aspect of the basement membrane became blurred, and the germinal epithelium overlying this area became squamous, however the theca interna cells were difficult to distinguish as such in normal animals as of the figures $(9,10)$, therefore the histological characteristics of the DF (17-25 $\mathrm{mm}$ ) is shown small antral and have a granulosa cell layer and internal theca cell layer, but the COF (diameter > $25 \mathrm{~mm}$ ) presented a large granulose cell layer as has been in figures $(11,12)$. 
AL-Qadisiya Journal of Vet.Med.Sci. of $5^{\text {th }}$ conference 21-22 Nov. 2012 Vol. 11 No. 3 2012

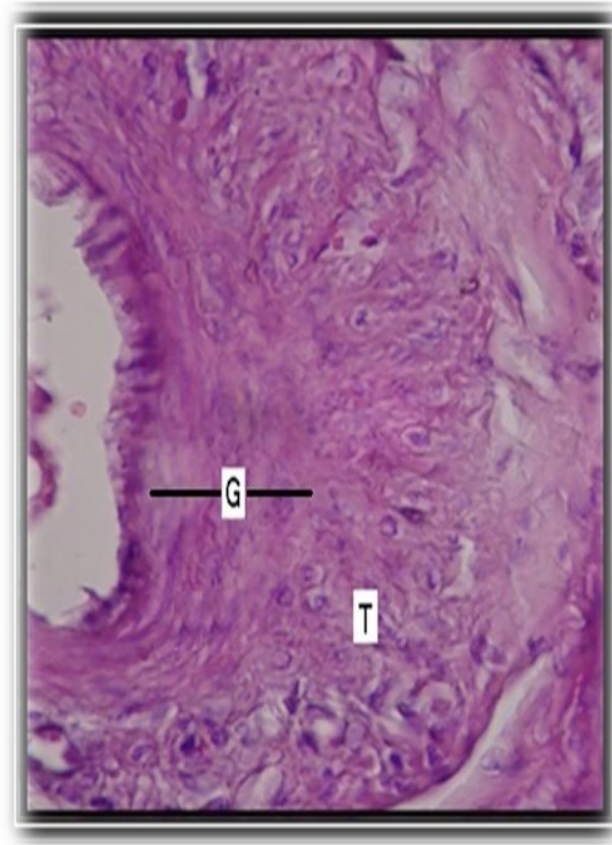

Figure (9):Hematoxylin and iosin-stined of the dominant follicles $(23 \mathrm{~mm}),(\mathrm{G})$ thickness Of the granulosa cell layer are $75.25 \mu ;(\mathrm{T})$ theca cell layer.

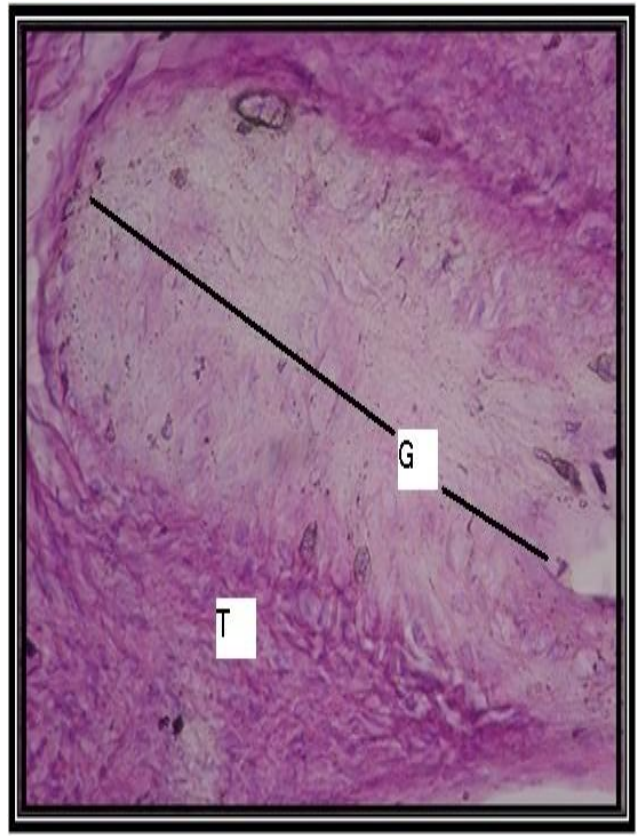

Figure (11): Hematoxylin and iosin-stined cystic follicles $(36.5 \mathrm{~mm}),(\mathrm{G})$ :thickness

the

granulosa cell layer are $(165 \mu \mathrm{m})$

$(\mathrm{T})$ : theca cell layer

\section{Follicular Fluid Hormonal assay}

The second line of this study are measured of $\mathrm{E} 2 \& \mathrm{P} 4$ concentration in the FF to

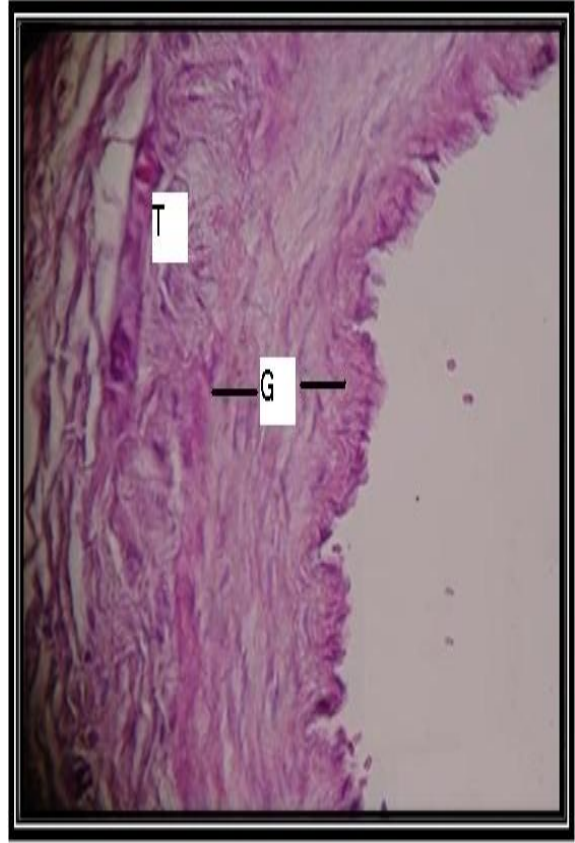

Figure (10): Hematoxylin and iosin-stined of the follicles $(18 \mathrm{~mm}),(\mathrm{G})$ thickness of the granulosa cell layer are $50.5 \mu$ ; (T) theca cell layer.

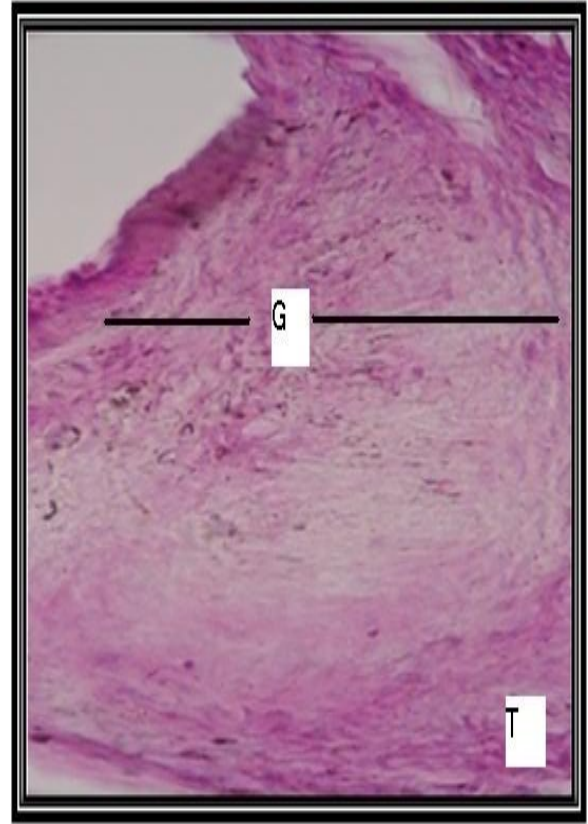

Figure (12): Hematoxylin and iosin-stined cystic follicles $(39 \mathrm{~mm}),(\mathrm{G})$ :thickness of of the granulosa cell layer are $(201 \mu \mathrm{m})$

(T): theca cell layer. .

identify the stages of the estrus cycle in bovine ovaries, and to verification of the steroidogenic status of the COF, by using a 
AL-Qadisiya Journal of Vet.Med.Sci. of $5^{\text {th }}$ conference 21-22 Nov. 2012 $\begin{array}{lll}\text { Vol. } 11 & \text { No. } 3 & 2012\end{array}$

RIA methods. The FF of COF have higher

E2 concentrations $865.96 \quad(800.1-919.3)$ $\mathrm{ng} / \mathrm{ml}$ with significant difference $(P>0.05)$ than did E2 concentrations in FF of the DF which are 314.39 (293.7-334.6) $\mathrm{ng} / \mathrm{ml}$, but the FF of COF show this have greater P4 concentrations levels 84.8 (73.6-95.6), $(P<$ $0.05)$ compared with those in DF was 50.25 (32.7-64.2) $\mathrm{ng} / \mathrm{ml}$, therefore the difference between E2 \& P4 concentration in the FF of DF and COF was significant $(P>0.50)$, also because the E2/P4 ratio was greater than one that's indication to the DF came from ovaries in the follicular phase of the estrus cycle and hormonally classified as healthy (estrogen active), as well as the COF were classified as oestrogen-active cysts because this ratio a greater than one and concentration of $\mathrm{P} 4$ less than hundred (E2/ P4 $>1$ and $\mathrm{P} 4<100$ $\mathrm{ng} / \mathrm{ml}$ in $\mathrm{FF}$ according of (11-12), as a table (3).

Table (3): The data are presented as mean (max-min) \pm Se. of 1.follicular size , 2.estradiol \& progesteron concentrations in the follicular fluid, 3. Granulosa cell layers thickness of the dominant follicles $(n=23)$ and cystic ovarian follicles $(n=21)$, $t$-test was used with $\mathrm{p}>0.05$ as the criterion for significance, $(*)$ sigificant differences of normal (DF) in ( $>>0.05)$.

\begin{tabular}{|c|c|c|c|c|c|}
\hline $\begin{array}{l}\text { Follicul } \\
\text { ar size }\end{array}$ & n. & Follicular siz & (E2)ng/ml in F.F. & $\begin{array}{l}\text { (P4) } n g / m l \text { in } \\
\text { F.F. }\end{array}$ & $\begin{array}{l}\text { Granulosa cell } \\
\text { layers } \\
\text { thickness } \\
(\mu \mathrm{m} .)\end{array}$ \\
\hline $\begin{array}{l}\text { Domina } \\
\text { nt } \\
\text { follicles }\end{array}$ & 23 & $\begin{array}{l}19.93 \\
23.4) \\
\pm 0.32\end{array}$ & $\begin{array}{l}314.39 \\
334.6) \\
\pm 2.55\end{array}$ & $\begin{array}{l}50.25 \quad(32.7- \\
64.2) \\
\pm 1.57\end{array}$ & $\begin{array}{l}57.69 \quad(26.25- \\
75) \\
\pm 2.38\end{array}$ \\
\hline $\begin{array}{l}\text { Cystic } \\
\text { ovarian } \\
\text { follicles }\end{array}$ & 21 & $\begin{array}{l}37.56(31-40) \\
\pm 0.64 *\end{array}$ & $\begin{array}{l}865.96 \quad(800.1- \\
919.3) \\
\pm 10.64 *\end{array}$ & $\begin{array}{l}\text { 84. } 8 \text { (73.6- } \\
95.6) \\
\pm 1.35^{*}\end{array}$ & $\begin{array}{l}193.18 \\
213) \\
\pm 2.51 *\end{array}$ \\
\hline
\end{tabular}

\section{Discussion}

The objective of the present study was to measurement of the concentration of steroid hormones in FF, The hormonal assay was revealed that the highest mean of E2 concentration 314.39 (293.7-334.6) $\mathrm{ng} / \mathrm{ml}$ in FF was recorded in the DF, and this level was $865.96(800.1-919.3) \mathrm{ng} / \mathrm{ml}$ in the $\mathrm{COF}$, these finding are in agreement with (23-24-25) who recorded of a high concentrations of E2 in COF and within the (26) who observed that the cows with developed cysts showed prolonged periods of high concentrations of E2 in conjunction with the development of the cysts . On the another hand (27) obvious Increased total steroid hormone contenting in DF may be a function of follicular diameter, as granulosa cell number and theca cell mass increase with follicular size .So (34) were presence that the concentrations of E2 in FF ( $\mathrm{ng} / \mathrm{ml})$ were higher in COF than in DF, but not different from young cysts. As for the mean of P4 level was 50.25 (32.7-64.2) $\mathrm{ng} / \mathrm{ml}$ in FF of the DF ,and increase to reach 84.8 (73.6-95.6) $\mathrm{ng} / \mathrm{ml}$ in the cows with $\mathrm{COF}$, these results are in agreement with (28) they suspected the concentrations of $\mathrm{P} 4$ in $\mathrm{FF}$ were higher on a ng/ follicle basis in COF than in DF, while (8) found that the concentrations of (P4) in FF ( $\mathrm{ng} / \mathrm{ml}$ ) were similar in dominant cysts and in DF, also the high E2 and a low of P4 concentration which indicated to the COF (23). while study of (32) were reported that intra follicular concentrations of E2 and P4 may change in cysts over time, and (35-36) were observed that the some COF which contain high concentrations of $\mathrm{P} 4$ in the $\mathrm{FF}$, the 
AL-Qadisiya Journal of Vet.Med.Sci. of $5^{\text {th }}$ conference 21-22 Nov. 2012

$$
\text { Vol. } 11
$$

reason of $\mathrm{P} 4$ secreted are not known, yet to differential between steroidal state of the $\mathrm{COF}$ were measured of the $\mathrm{E} 2$ and $\mathrm{P} 4$ concentrations in $\mathrm{FF}$, a ratio $(\mathrm{E} 2 / \mathrm{P} 4>1)$ in FF of normal follicles, this a result are close to that obtained by (33-34) Similar results were obtained (10) was referred that the $\mathrm{COF}$ were oestrogen-active (E2/ P4 > 1 and $\mathrm{P} 4<100 \mathrm{ng} / \mathrm{ml} \mathrm{FF}$ ). The COF which used in this study containing large thickness of granulosa cells layers in mean of (193.18) $\mu \mathrm{m}$ and range around between (175-213) $\mu \mathrm{m}$. ,than did granulose cell layer thickness of DF with (57.69) in range (26.25-75) $\mu \mathrm{m}$.,

\section{References}

1. Gordon,L.,(2002).Oestrus and the oestrus cycle in cattle. in: Controlled Reprod-uction in cattle and buffaloes. 2th Edition .C.A.B. international company . USA. pp: 123-124.

2. Youngquist, R. S. and Threlfall W. R.,(2007). Ovarian Follicular Cysts. Current Therapy in Large Animal Theriogenology. St. Louis, MO: Saunders Elsevier. 379-383.

3. Ashmaway, A.A.; Vogt, R.S.; Youngquist, H.A.; Garverick,( 1990). Heritability of liability to cystic ovary development in Holstein cattle. J Hered. 81:165-166.

4. Peter, A.T.,( 2004). An update on cystic ovarian degeneration in cattle. Reprod. Domest.Anim. 39: 1-7.

5. Yoshioka, K.; Iwamura, S. and Kamomae, H.,( 1996). Ultrasonic observations on the turnover of ovarian follicular cysts and associated changes of plasma $\mathrm{LH}, \mathrm{FSH}$, progesterone and oestradiol-17 $\beta$ in cows. Res. Vet. Sci. 61: 240-244.

6. Wiltbank, M.C.; Gumen, A. and Sartori, R.,(2002).Physiological classification of anovulatory conditions in cattle. Theriogenology $.57: 21-52$.

7. Calder, M.D. ; Manikkam, M. ; Salfen, B.E. ; Youngquist, R.S. ; Lubahn D.B. ; Lamberson, W.R. and Garverick, H.A.,(2001).Dominant bovine ovarian follicular cysts express increased levels of messenger RNAs for luteinizing hormone receptorand 3hydroxysteroid

dehydrogenase_4,_5 isomerase compared to normal dominant follicles.Biology of Reproduction.65:47-16.

8. Silvia, W.J. ; Hatler, T.B.; Nugent, A.M. ; Laranja, D.A.and Fonseca, L.F.,( 2002). Ovarian follicularcysts in dairy cows: an abnormality in folliculogenesis. Domestic Animals Endocrinology. 23:167177.

9. Zhenzhong, X.U.; Allen, G. ; George, W. ; Michael, F. ; Stacey, A. ; Hamilton ; Robert, S. and Youngquist., (1995). Expression of Follicle-Stimulating Hormone and Luteinizing Hormone Receptor Messenger Ribonucleic Acids in Bovine Follicles during the First Follicular Wave. biology of reproduction $.53: 951-957$. 
AL-Qadisiya Journal of Vet.Med.Sci. of $5^{\text {th }}$ conference 21-22 Nov. 2012

\section{Vol. 11}

10. Ball,P. J.and Peters,A.R., (2004). Reproductive Problems. Reproduction in Cattle.Oxford, UK: Blackwell Pub.pp:172-175.

11. Echternkamp,S.E. ; Roberts, A. J.; Lunstra,D. D.;Wise, T.and Spicer, L.J.,(2004). Ovarian follicular development in cattle selected for twin ovulations and births.J. Anim.Sci.82:459-471.

12. Hatler, T.B.; Hayes, S.H.; Laranja da Fonseca, L.F. and Silvia, W.J. , (2003).Relationship Between Endogenous Progesterone and Follicular Dynamics in Lactating Dairy Cows with Ovarian Follicular Cysts1. Biology of Reproduction .69: 218-223.

13. Sciorsci, R.L.; Robbe, D.; DImatteo, A.; LA-calandra, G.M. and Minoia, P.,(2000). The treatment of ovarian follicular cystis in dairy cow with epidural calcium-naloxone and systemic gnarl administration: a preliminary field study. $14^{\text {th }}$. International Congress on Animal Reproduction Stockholm. 12:7-13.

14. Grado-Ahuir, J. A. ; Aad, P.Y. and Spicer, L.J., (2009). Microarray analysis of bovine granulosa cells from normal and cystic follicles. American Society of Animal Science. 60:312-315.

15. Isobe,N.; Kitabayashi, M. and Yoshimura, Y.,(2008). Expression of Vascular Endothelial Growth Factor Receptors in Bovine Cystic Follicles. Reprod Dom Anim. 43: 267-271 .

16. Berisha, B.; Schams, D. ; Kosmann, M. ; Amselgruber, W. and Einspanier, R.,(2000a). Expression and tissue concentration of vascular endothelialgrowth factor, its receptors, and localization in the bovine corpusluteum during estrous
No. 3 2012

cycle and pregnancy. Biology of Reproduction.63:1106-1114.

17. Stock, A.E. and Fortune, J.E., (1993). Ovarian follicular dominance in cattle: relationship between prolonged growth of ovulatory follicle and endocrine parameters. Endocrinology.132:1108-1114.

18. Vanholder, T., (2005). Cystic ovarian follicles in the high yielding dairy cow post partum.J. Rep. Neutr. Dev.46:127-150

19. Adeyemo, O. ,(1984).Plasma and milk progesterone in the early diagnosis of cattle pregnancy. Proceedings of the Fall Conference of the Society of Theriogenology, Sept. 26, Denver, Colorado, U.S.A.

20. Adeyemo, O.; Heath, E.; Adadevoh, B. K.and Steinbach, J., (1981). Plasma cortisol in Bos Taurus and Bos indicus heifers in seasonal tropical climate. J. Dairy Sci. 64:1585-1592.

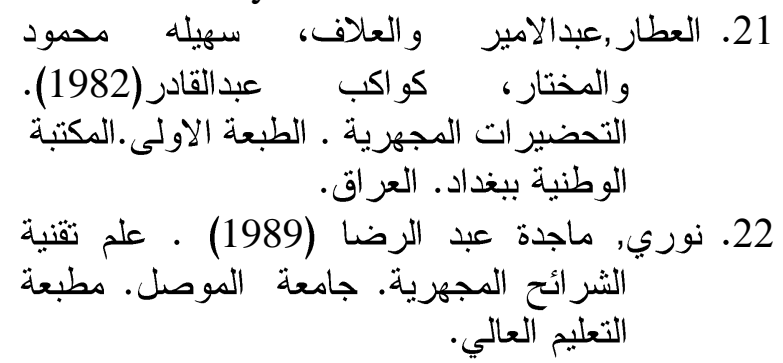

23. Fortune, J.E. ; Rivera, G.M. ; Evans, A.C.O. and Turzillo, A.M. ,(2001). Differentiation of Dominant Versus Subordinate Follicles in Cattle. Biology of Reproduction .65 : 648-654.

24. Sirois, J.; Fortune, J.E. and Lengthening , (1990). The bovine estrous cycle with low levels of exogenous progesterone: a model for studying ovarian follicular dominance. Endocrinology $.127: 916-25$. 
AL-Qadisiya Journal of Vet.Med.Sci. of $5^{\text {th }}$ conference 21-22 Nov. 2012

Vol. 11

25. Wehrman, M.E.; Roberson, M.S. ;

Cupp, A.S. ; Kojima, F.N. ;

Stumpf, T.T.; Werth, L.A. ;

Wolfe, M.W. ; Kittock, R.J. and

Kinder, J.E.,(1993). Increasing exogenous progesterone during estrous synchronization decreases estrogen and increases conception in cows. Biol. Reprod. 49:214-20.

26. Savio,J. D.; Boland, M. P. ; Hynes, N. and Roche, J. F.,(1990). Resumption of follicular activity in the early post-partum period of dairy cows.J.Reprod.fert. 88:569-579.

27. Ireland, J.J. and Roche, J.F.,(1983). Development of non-ovulatory natural follicles in heifers: changes in steroids in follicular fluid and receptors for gonadotropins. Endocrinology .112:150-156.

28. Webb, R. ; Gauld, I.K. and Driancourt, M.A., (1989). Morphological and functional characteristics of large antral follicles in three breeds of sheep with different ovulation rates. J. Reprod. Fertil. 87:243255.

29. Cantley, T.C. ; Garverick, H.A. ; Bierschwal, C.J. ; Martin, C.E. ; and Youngquist, R.S., (1975). Hormonal response of dairy cows with ovarian follicular cysts to GnRH. J. Animal Sci. 41:1666-1673.

30. Fortune, J. E. and Hansel, W., (1979a). Effects of the LH surge on steroid secretion by theca and granulose cells of bovine preovulatory follicles. Biol. Reprod. 20(Suppl. 1):46a.

31. Fortune, J. E. ,(1981). Bovine theca and granulosa cells interact to
No. 3

2012

promote androgen and progestin production.Biol. Reprod. 24

(Suppl. 1): 39a.

32. Fortune, j. E. and Hansel, W., (1985). Concentrations of Steroids and Gonadotropins in Follicular Fluid from Normal Heifers and Heifers Primed for Superovulation. Biology of Reproduction. 32: 1069-1079.

33. Badinga, L. ; Driancourt, M.A. ; Savio, J.D. ; Wolfenson, D. ; Drost, M. ;De La Sota, R.L. and Thatcher,W.W., (1992). Endocrine and ovarian responses associated with the first-wave dominant follicle. Biology of Reproduction. 47: 871-883.

34. Landau, S. ; Braw-Tal, R. ; Kaim, M. ; Bor, A. and Bruckental, I., (2000). Preovulatory follicular status and diet affect the insulin and glucose content of follicles in high-yielding dairy cows. Animal Reproduction Science. 64: 181197.

35. Boryczko, Z.; Bostedt, H. and Hoffmann, B.,(1995). Comparison of hormonal and chemical composition of the fluid from bovine ovarian follicles and cysts. Reprod. Domestic Animal. 30:36-38.

36. Borromeo,V. ; Bramani, S. ; Berrini, A. ; Sironi, G. ; Finazzi, M.; Cremonesi, F. and Seccgi, C.,(1996).Growth hormone but not prolactin concentrations in the fluid of bovine ovarian cysts are related to the cystic stage of luteinization. Theriogenology. 46:481-489. 
AL-Qadisiya Journal of Vet.Med.Sci. of $5^{\text {th }}$ conference 21-22 Nov. 2012 Vol. 11 No. 3

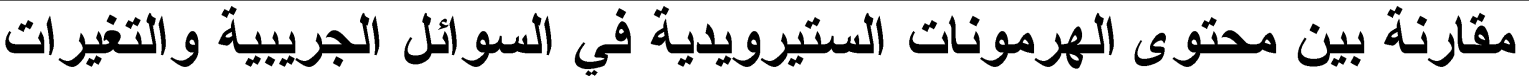 النسيجية للجريبات السائدة والمتكيسة في سلاتلات الأبقار المحلية.

$$
\text { علاء كامل عبدالله }
$$

التكيس الجريبي هو سبب خطير لفشل الإخصاب في الأبقار لأنه يحدث بصورة متكررة ويؤدي إلى إطالة الفترة

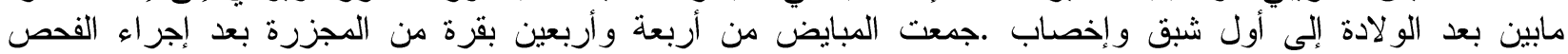

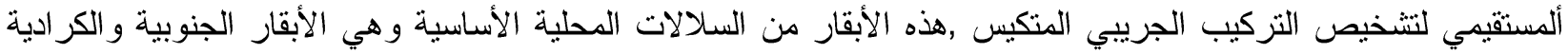

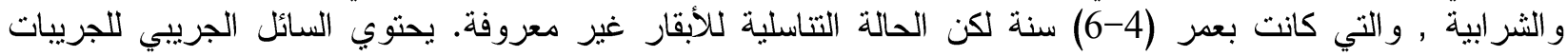
السائدة على تركيز عالي معنويا (p>0.05) من هرمون الاستر ادايول و البروجسترون اكثر مما موجود في سائل الجريبات

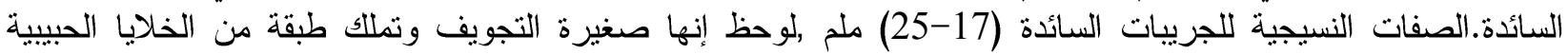

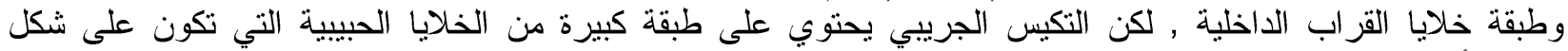

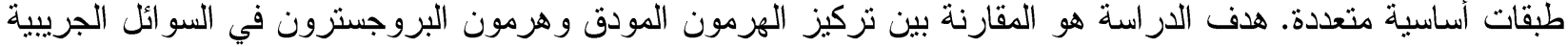

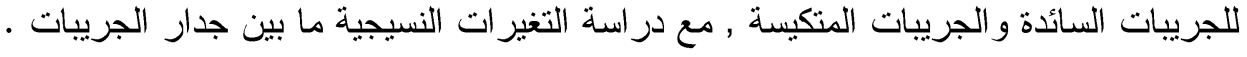

